\title{
EDitorial EDitorial
}

Este número da Temporalis, que ora apresentamos ao público, é o último organizado, integralmente, pela gestão 2010-2012 da Associação Brasileira de Ensino e Pesquisa em Serviço Social (ABEPSS), constituindo-se no coroamento do esforço realizado para impulsionar o processo de qualificação da revista. Assim, a Diretoria Nacional e a Comissão Executiva da Temporalis agradecem e reconhecem o esforço de todos que contribuíram, enviando artigos e atuando como pareceristas e como membros do conselho editorial, incluindo os estudantes de graduação, que ofereceram valioso apoio a este trabalho. Em especial, nossas palavras se dirigem, mais uma vez, às professoras Jussara Maria Rosa Mendes e Maria Lúcia Teixeira Garcia. Reafirmando ainda nosso compromisso com a entidade, esta diretoria se responsabiliza por deixar encaminhada a próxima edição, a fim de que a próxima gestão tenha condições de manter a periodicidade da revista.

Foi aprovada, em reunião com os editores, durante a realização da Oficina Nacional da ABEPSS, em 2011, que, sendo a Temporalis representativa da área do Serviço Social, a conquista de apoio financeiro da Coordenação de Aperfeiçoamento de Pessoal de Nível Superior (CAPES) torna-se estratégica para nossa entidade nacional de ensino e pesquisa. Estamos cientes de que vários requisitos são necessários para que um periódico científico atenda às exigências de qualificação e obtenha financiamento. Nesse sentido, temos a satisfação de afirmar que a Temporalis se apresenta como uma revista que atende aos critérios requeridos por essa entidade de fomento. 
A escolha da temática deste número, "Questão Agrária, Urbana, Ambiental e Serviço Social”, se expressa como uma das iniciativas de afirmar e qualificar o debate conduzido pelos Grupos Temáticos de Pesquisa (GTP) da ABEPSS. O GTP que se dedica à discussão do tema participou ativamente desta edição, enviando artigos, elaborando os pareceres, fazendo e dando entrevistas e tecendo articulações junto a autores e sujeitos coletivos, que generosamente nos brindaram e nos desafiaram com suas produções e lutas.

A importância da temática de pesquisa em tela para o Serviço Social pode ser expressa pelo grande desafio assumido como proposição desse GTP: aprofundar a construção de fundamentos teórico-metodológicos, em uma perspectiva de totalidade, para embasar tanto a análise crítica das expressões da questão social no âmbito da questão agrária, urbana e ambiental, em sua materialidade na realidade brasileira, como as estratégias de intervenção profissional nestes campos. Assim, propusemos os seguintes eixos para o debate: I. Determinações estruturais e históricas da questão urbana, agrária e ambiental no Brasil: a luta de classes como mediação; II. O papel do Estado e as políticas públicas no campo e cidade; III. Invisibilidade ou visibilidade negativa dos movimentos sociais de luta pela terra na cidade e no campo. Com base nessa perspectiva, traçamos o perfil das seções deste número.

\section{Seção Debate}

Trazemos neste número a participação de um renomado intelectual latino-americano, o uruguaio Guillermo Foladori, professor da Universidade Autônoma de Zacatecas (México), que também nos brinda com sua participação no XIII ENPESS. A instigante produção apresentada por esse autor diz respeito à criação e ao uso das nanotecnologias (NT), tema ainda pouco conhecido e debatido, principalmente nas Ciências Sociais. O texto intitulado "La nueva revolución tecnológica y sus impactos a la salud de los trabajadores" é debatido pelo professor e militante Pedro Cristófoli, representando o Movimento de Trabalhadores Rurais Sem-terra do Brasil (MST), e pela professora Mônica A. Grossi Rodrigues, da UFJF, membro da atual diretoria nacional da ABEPSS e do GTP "Questão Agrária, Urbana, Ambiental e Serviço Social”. As questões trazidas ao debate se relacionam à apropriação capitalista da ciência e tec- 
nologia na agricultura, estabelecendo uma relação entre transgênicos e as NT, e ao metabolismo social do capital, que ao engendrar novas tecnologias, como as NT, impõe sérios desafios políticos aos trabalhadores, tendo em conta os riscos à saúde e ao meio ambiente.

\section{Seção Temática}

Constitui-se de artigos subdivididos em três grupos temáticos. Contamos com a produção dos membros do GTP citado anteriormente, os quais submeteram, com os procedimentos usuais de sigilo de autoria, seus artigos à avaliação.

O grupo temático “Questão Agrária” agrega o maior número de produções e trata de questões da maior relevância, expressas nos seguintes artigos: "Cooperação e hegemonia na dinâmica do capitalismo contemporâneo: organização produtiva do MST no Ceará”, de Eveline Medeiros Pereira (IFCE); "Agricultura de sustentação sob os olhares de Josué de Castro", de Sirlândia Schappo (UFSC); "Notas sobre a questão agrária haitiana", de Thalles Gomes (Faculdade Anhanguera); "Como os dominantes dominam: o caso da bancada ruralista", de Ivete Simionatto e Carolina Rodrigues Costa (UFSC); “Questão social' no Brasil: o nordeste e a atualidade da questão regional", de Josiane Soares Santos, Laiane Conceição de Vasconcelos, Thamiris de Oliveira Natale e Radaine Dayan Acciole de Figueiredo (UFSC).

O grupo "Questão Urbana” contempla uma clara articulação com o Serviço Social, apresentando três trabalhos: "A questão urbana e a produção acadêmica do Serviço Social brasileiro em foco", de Maria Clariça Ribeiro Guimarães, Eliana Costa Guerra e Raquel Cardozo da Silva (UFRN); "Concepção de cidade na obra dos clássicos da teoria social”, de Gabriela Lema Icasuriaga e Maria Helena Rauta Ramos (UFRJ); “O cenário da política urbana brasileira e o Serviço Social: contribuições para o debate”, de Mauricléia Soares dos Santos (Faculdades Mauá e Faculdades Metropolitanas Unidas), Núria Pardillos Vieira (PUC-SP) e Tânia Maria Ramos de Godoi Diniz (Universidade Federal de São Paulo - Baixada Santista).

A questão ambiental é especificamente tematizada em uma reflexão não só relevante como também indispensável e urgente. Com 
o título "Economia verde: a nova ofensiva ideológica do ecocapitalismo”, Nailsa Maria Souza Araújo e Maria das Graças e Silva (UFPE) problematizam a ideia central defendida na Conferência Oficial da Rio +20 , realizada em 2012, que se refere à possibilidade e/ou viabilidade de um "capitalismo verde". Destacamos que uma das autoras, Maria das Graças e Silva, é uma das coordenadoras do GTP anteriormente citado, além de uma das referências, no Serviço Social brasileiro, na discussão da questão ambiental.

No encontro das temáticas agrária e ambiental, temos o artigo "Privatização da terra: intersecções das questões agrária e ambiental", de Vanda de Aguiar Valadão e Gilsa Helena Barcellos (UFES). Já o artigo "Questão agrária, urbana e ambiental na Amazônia brasileira: notas para o debate", de Nádia Socorro Fialho Nascimento (UFPA), se propõe ao desafio de articular estes três grupos, na análise do papel desta região no desenvolvimento capitalista, tendo em vista a importância da exploração da natureza para o processo produtivo.

\section{Seção de temas livres}

Os quatro artigos que integram esta seção discutem questões muito caras ao Serviço Social, como desenvolvimento, pobreza, microcrédito, informalidade, conselhos de direitos e o Sistema Único de Assistência Social.

\section{Seção ensaio}

Aqui, um dos mais brilhantes e renomados intelectuais do pensamento crítico, o belga François Houtart, nos contempla com uma reflexão sobre a Cúpula dos Povos, a Rio +20 e o bem comum da humanidade.

\section{Seção entrevista}

A entrevista apresentada foi elaborada por uma das coordenadoras do GTP em destaque nesta edição, a professora Maristela Dal Moro (UFRJ), tendo como entrevistada a professora e militante da questão agrária no Serviço Social, professora Severina Garcia (UFRN), considerada uma das grandes referências do Serviço Social na discussão da temática agrária.

\section{Seção documentos}

Para finalizar, esta seção traz a ementa do GTP “Questão Agrária, 
Urbana, Ambiental e Serviço Social, as campanhas da Via Campesina sobre o combate aos agrotóxicos e sobre as sementes como patrimônio dos povos a serviço da humanidade e, ainda, um relatório de viagem contendo uma síntese da reunião do Serviço Social Radical, realizada no Congresso Internacional de Estolcomo, em 2012.

Na certeza da diversidade e da riqueza das discussões que este número da Temporalis abrange, desejamos a todos uma ótima leitura.

Gestão ABEPSS 2010-2012 